\title{
The Clinical Significance of DNA Ploidy Analysis in Patients with Rectal Carcinoma and Precancerous Lesion
}

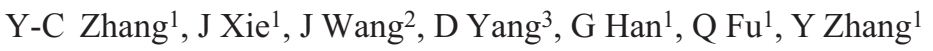

\begin{abstract}
Objectives: In recent years, DNA ploidy analysis is regarded as having important values in diagnosis and prognostic judgment of malignant tumour. The aim of this study was to explore the clinical significance of DNA ploidy analysis in patients with rectal carcinoma and its precancerous lesions.

Subjects and method: Flow cytometry was used to measure the DNA content and ploidy status in normal, precancerous and cancerous fresh rectal tissues. These rectal tissues came from 325 individuals including 120 patients with rectal carcinoma, 25 with proliferative polyps, 155 with villous adenoma and 25 normal controls. The occurrence of DNA heteroploidy was analysed.

Results: The positive rate of heteroploidy in patients with rectal carcinoma was significantly higher than that in individuals with proliferative polyps, villous adenoma and normal controls. The positive rate of heteroploidy in patients with villous adenoma with severe atypical proliferation was much higher than that in proliferative polyps, normal controls, and villous adenoma without atypical proliferation, villous adenoma with mild-or-moderated atypical proliferation. The occurrence of DNA heteroploidy was significantly increased with poorer degree of differentiation in rectal carcinoma.

Conclusion: The detection of DNA ploidy could be a valuable tool to evaluate the proliferation status and malignant degree of rectal carcinoma. The analysis of DNA ploidy may play an important role in the diagnosis, differential diagnosis, assessment of disease progression and prognosis of rectal carcinoma.
\end{abstract}

Keywords: DNA ploidy, flow cytometry, precancerous lesion, rectal carcinoma

\section{La Significación Clínica del Análisis de Ploidía del ADN en Pacientes con Carcinoma Rectal y Lesión Precancerosa}

\author{
Y Zhang ${ }^{1}$, J Xie ${ }^{1}$, J Wang ${ }^{2}$, D Yang ${ }^{3}$, G Han ${ }^{1}$, Q Fu ${ }^{1}$, Y Zhang ${ }^{1}$
}

\begin{abstract}
RESUMEN
Objetivos: En los últimos años, se considera que el análisis de ploidía del ADN tiene valores importantes en el diagnóstico y pronóstico de los tumoures malignos. El objetivo de este estudio fue explorar la significación clínica del análisis de ploidia del ADN en pacientes con carcinoma rectal y sus lesiones precancerosas.

Sujetos y método: La citometría de flujo se utiliza para medir el estado del contenido y ploidía de ADN en tejidos rectales frescos normales, precancerosos y cancerosos. Estos tejidos rectales provenían de 325 individuos incluyendo 120 pacientes con carcinoma rectal, 25 con pólipos proliferativos, 155 con adenoma velloso, y 25 controles normales. Se analizó la presencia de heteroploidia del ADN.

Resultados: La tasa positiva de heteroploidia fue significativamente mayor en pacientes con carcinoma rectal que en los individuos con pólipos proliferativos, adenoma velloso y los controles normales. La tasa positiva de heteroploidía fue mucho mayor en pacientes con adenoma velloso con severa proliferación anormal que en los pacientes con pólipos proliferativos, adenoma velloso sin proli-feración anormal, adenoma velloso con proliferación anormal leve o moderado, y los controles normales. La aparición heteroploidía se incrementó significativamente con un grado más pobre de diferenciación en el carcinoma rectal.
\end{abstract}

From: ${ }^{1}$ Department of General Surgery, The Affiliated Cancer Hospital of Zhengzhou University / Henan Cancer Hospital, Zhengzhou, Henan, 450003, China, ${ }^{2}$ Department of Surgery, First Affiliated Hospital of Zhengzhou University, Zhengzhou, Henan, 450052, China and ${ }^{3}$ Department of Medical Oncology, Fox Chase Cancer Center, Philadelphia, Pennsylvania, 19111, USA.
Correspondence: Dr Y Zhang, Department of General Surgery, The Affiliated Cancer Hospital of Zhengzhou University/Henan Cancer Hospital, Zhengzhou, Henan, 450003, China. Email: zhangycqh@yahoo.com. 


\begin{abstract}
Conclusión: La detección de la ploidía del ADN podría ser una herramienta valiosa para evaluar el estado de proliferación y el grado de malignidad del carcinoma rectal. El análisis de la ploidía del ADN puede desempeñar un papel importante en el diagnóstico, el diagnóstico diferencial, la evaluación de la progresión de la enfermedad, y el pronóstico de carcinoma rectal.
\end{abstract}

Palabras claves: Ploidía del ADN, citometría de flujo, lesión precancerosa, carcinoma rectal

West Indian Med J 2016; 65 (3): 552

\section{INTRODUCTION}

Colorectal carcinoma $(\mathrm{CRC})$ is the third most common malignancy presenting serious threat to human health worldwide, and one-third is represented by rectal carcinoma, which accounts for approximately $40 \%$ of all colorectal carcinoma deaths (1). Similarly, rectal carcinoma is a malignant tumour with high incidence in China and its incidence has been increasing. In China, the incidence of rectal carcinoma is higher than that of colonic carcinoma. Retrospective data from China demonstrate that rectal carcinoma accounts for $59.4-71 \%$ of the total number of CRC patients (2-4).

The main reasons related to the poor treatment outcome of rectal carcinoma are invasion and metastasis of the tumour to adjacent and distant organs (5). In recent years, progress has been made in understanding the proliferation kinetics and cell cycle regulation of the tumour. Early detection of the tumour from the level of cell and molecular biology is regarded to be critical to achieve early treatment and improve the treatment outcome. Currently, although basic research of malignant tumour has entered the era of molecular biology, the pathological diagnosis of rectal carcinoma and precancerous lesions is still based on traditional microscopic observation of spatial structure and changes in cell morphology (6).

Due to the inherent limitations of morphological studies, judgments and descriptions of tumours by experience are often affected by subjective factors such that the pathological diagnosis is sometimes too conservative or too aggressive. It is well known that the most important biological characteristics of malignancy includes: 1) abnormal proliferation and differentiation, 2) invasiveness and metastasis, and 3) genetic alteration of tumour cells. These common biological characteristics of cancer cells could be reflected by the abnormalities of nuclear DNA content and/or change of chromosome ploidy and function (7). Therefore, detection and analysis of nuclear DNA content and DNA ploidy will have important values in pathological diagnosis of malignant tumour, particularly in determination of the degree of malignancy, evaluation of curative options and predict prognosis.

In this study, we used flow cytometry to analyse intracellular DNA content and DNA ploidy in different categories of rectal lesions. We investigated the correlation of intracellular DNA ploidy and DNA index with rectal carcinoma and rectal precancerous lesions. We explored if detection of DNA ploidy could assist with diagnosis and prognostic judgment of rectal carcinoma.

\section{SUBJECTS AND METHODS}

\section{Specimen characteristics}

This study was approved by the Internal Review Board of Henan Cancer Hospital. Tissue samples were obtained from 325 individuals who gave informed consent. These tissue samples were collected from 120 patients with rectal carcinoma, 25 patients with proliferative polyps, 155 patients with villous adenoma and 25 healthy individuals (Figure). All of the 120 patients with rectal carcinoma underwent surgery in Henan Cancer Hospital and the surgically removed samples were collected for this study. Patients with rectal carcinoma had a median age of 59.76 years (ranging from 41 to 78 years). There were 73 males and 47 females who participated in this study. These 120 patients were distributed in four pathological categories.

Thirty-three patients had well differentiated adenocarcinoma. Moderately differentiated adenocarcinoma, poorly differentiated adenocarcinoma and mucinous adenocarcinoma (including Signet Ring Cell Carcinoma) were found in 29, 31 and 27 patients, respectively (Table 1). Tissues of patients with proliferative polyps, villous adenoma and healthy individuals were obtained by colonoscopy and rectal mucosa biopsies. Among the 155 patients with villous adenoma, 30 cases had no atypical proliferation, 125 cases had atypical proliferation. All specimens were sent to the Department of Pathology for pathological evaluation. Then the specimens were processed for DNA ploidy analysis using flow cytometry.

\section{Reagents and instruments}

EPICS-XL flow cytometer was purchased from Beckman Coulter (USA). All the reagents used in the DNA ploidy analysis were acquired from Beckman Coulter (USA). Propidium iodide (PI) fluorescent dye was used as nuclear stain in the experiment.

\section{Preparation of single cell suspensions}

Fresh tissue pieces were put into a petri dish and washed by Phosphate-buffered saline (PBS). Fat and other unwanted tissues were trimmed off. Small tissue pieces were put into a test tube and $5 \mathrm{~mL}$ tissue lysate was added into the test tube. The tissue pieces were cut further to homogenates with an ophthalmic scissors. The tissue homogenates were pipetted and filtered into a test tube by copper mesh filter with 500 mesh. After 10 minutes of centrifugation (1500 r/minutes), the precipitate was washed three times with PBS to remove cell debris. Then 350-mesh nylon mesh filter was used to remove 


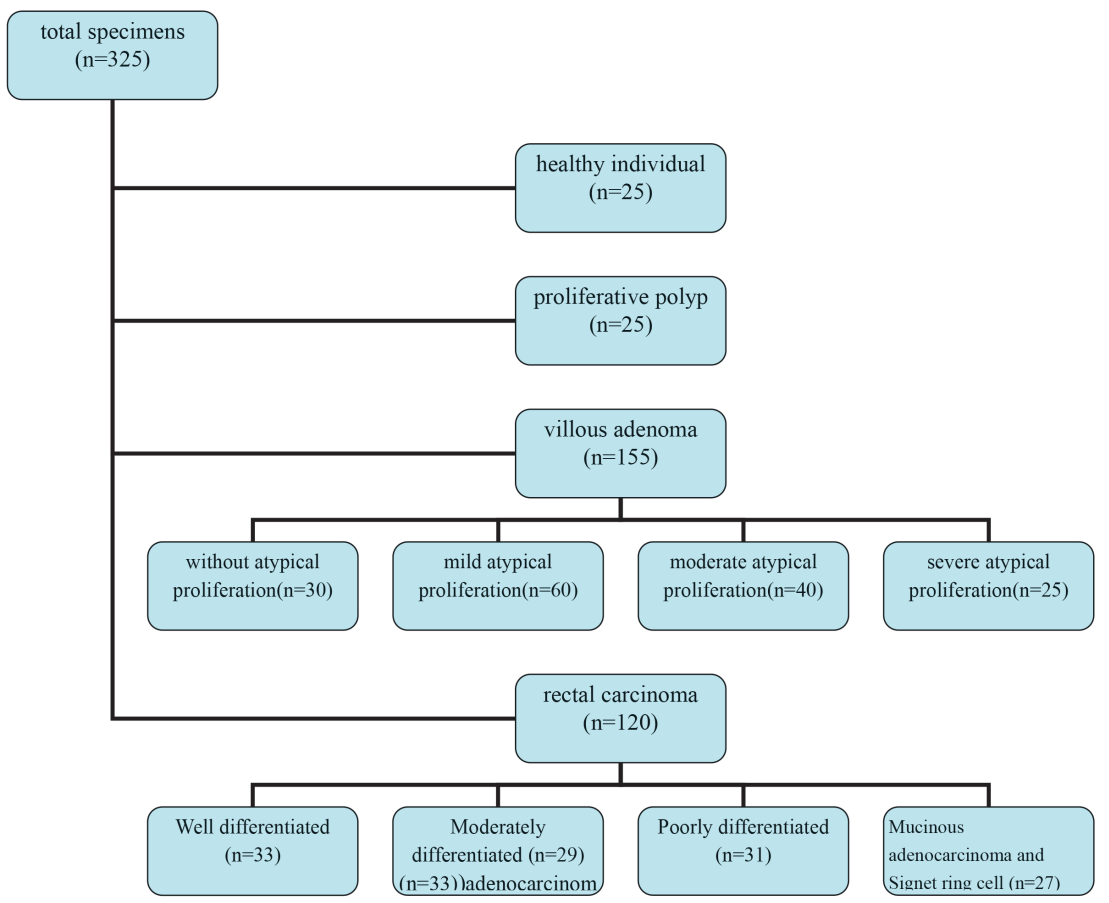

Figure: Grouping of specimens

Table 1: Rectal carcinoma patient characteristics

\begin{tabular}{lll}
\hline Patient characteristics & Number of patients \\
\hline Age & (years) & $59.76(41-78)$ \\
Gender & Male & 73 \\
pathological categories & Female & 47 \\
& $\begin{array}{l}\text { Well differentiated } \\
\text { adenocarcinoma }\end{array}$ & 33 \\
& $\begin{array}{l}\text { Moderately differentiated } \\
\text { adenocarcinoma }\end{array}$ & 29 \\
& $\begin{array}{l}\text { Poorly differentiated } \\
\text { adenocarcinoma }\end{array}$ & 31 \\
& $\begin{array}{l}\text { Mucinous adenocarcinoma } \\
\text { and Signet ring cell carcinoma }\end{array}$ & 27 \\
\hline
\end{tabular}

Age: median age (age-range); the rest of figures: number of samples

agglomerate cell clumps. The cell suspension was collected and was added with $70 \%$ cold ethanol for fixation. Cells were stored into a refrigerator at $4{ }^{\circ} \mathrm{C}$ for use in analysis.

\section{DNA staining}

The cold ethanol fixed specimens were taken out and washed with PBS. After centrifugation and precipitation, the supernatant was removed, then PI staining solution was added to the precipitate. After incubation in a refrigerator at $4{ }^{\circ} \mathrm{C}$ for 20 minutes, the specimens were filtered with 350 -mesh nylon mesh filter. Subsequently the PI stained cells were put into the flow cytometer for DNA ploidy analysis.

\section{Detection of DNA and calculation of DNA index (DI)}

All samples were analysed with the EPICS-XL flow cytometer. Before analysis, the instrument was calibrated using lym- phocytes from healthy individuals. Multicycle software was employed to analyse the results.

DNA index (DI), which indicates the relative content of DNA, was calculated using the formula: $\mathrm{DI}=$ the average channel value of sample to be tested at $\mathrm{G} 0 / \mathrm{G} 1$ peak/the average channel value of control sample at G0/G1 peak.

\section{Criteria of DNA ploidy definition}

The DNA ploidy was determined based on the DI value. The DI value of $0.90 \sim 1.10$ was classified as diploid, and the rest as heteroploidy ( $<0.85$ for hypodiploidy, $0.85 \sim 0.9$ or $1.1 \sim$ 1.15 for near diploid, $>1.15$ for hyperdiploidy).

\section{Statistical Methods}

F-test was used to calculate measurement data, $\chi^{2}$ test was used to calculate count data, $p<0.05$ was considered significant.

\section{RESULTS}

DNA ploidy status of specimens

DNA heteroploidy was not detected in normal rectal mucosa and hyperplastic polyps. The positive rate of heteroploidy in villous adenoma without atypical proliferation, with mild, moderate, and severe atypical proliferation, were $10.00 \%$ (3/30), 13.33\% (8/60), 15.00\% (6/40), 44.00\% (11/25), respectively. The positive rate of heteroploidy in rectal carcinoma was $76.67 \%(92 / 120)$. The results showed that there were significant differences in the positive rate of heteroploidy between rectal carcinoma group and the other groups $(p<0.01)$. There were also significant differences in the positive rate of heteroploidy of villous adenoma with severe atypical proliferation compared with normal controls, 
proliferative polyps, villous adenoma without atypical proliferation, villous adenoma with mild or moderate atypical proliferation $[p<0.01]$ (Table 2 ). This result indicated that with the increased severity of the disease, the positive rate of DNA heteroploidy increased accordingly.

DNA index (DI) analysis of DNA heteroploid in rectal carcinoma with different degree of differentiation. DNA index value in moderately differentiated adenocarcinoma (1.43 \pm 0.18 ) was higher than that in well differentiated adenocarcinoma $(1.15 \pm 0.12)$. The difference in these two groups was of statistical significance $(p<0.01)$. DNA index value in poorly differentiated adenocarcinoma $(1.70 \pm 0.23)$ was higher than that in moderately differentiated adenocarcinoma, and there was a statistical significance $(p<0.01)$ as well. There was no significant difference between DI value in poorly differentiated adenocarcinoma and that in mucinous adenocarcinoma (including Signet ring cell carcinoma) $[1.72 \pm 0.27](p>0.05)$ (Table 3). It was therefore suggested that DI value of DNA heteroploidy, increased with poorer differentiation of rectal carcinoma.

\section{DISCUSSION}

The intracellular DNA ploidy status can be detected by flow cytometry (8). DNA content and its ploidy status are critical for cell proliferation and heteroploid could be an important marker of cancerous change in cells. Previous studies showed that the occurrence of DNA heteroploidy had positive correlation with cell proliferation, degree of malignancy and poor prognosis (9-12). Therefore, the detection of DNA heteroploid by flow cytometry can judge the nature and trend of precancerous lesions, and could be helpful in the early diagnosis of cancer (13).

Normal cells are diploid with constant DNA content. In contrast, abnormalities of DNA content and/or chromosome structure are fairly common in the process of cancerous change $(14,15)$. The occurrence of DNA heteroploidy in cells indicated a process from quantitative change to qualitative change, which demonstrated that the cells had become cancerous or had the possibility of developing into cancer, although at this time point they might not meet the diagnostic criteria for cancer in Pathology. Researchers believed that the higher the degree of atypical hyperplasia in precancerous lesions, the greater

Table 2: The DNA ploidy status in rectal tissues

\begin{tabular}{lcccc}
\hline Pathologic diagnosis & n & \multicolumn{3}{c}{ DNA ploidy status } \\
\cline { 3 - 5 } & & $\begin{array}{c}\text { numbers of } \\
\text { heteroploid }\end{array}$ & $\begin{array}{c}\text { numbers of } \\
\text { diploid }\end{array}$ & $\begin{array}{c}\text { positive reate } \\
\text { of heteroploid }\end{array}$ \\
\hline Normal tissue & 25 & 0 & 25 & $0.00^{(1)(2)}$ \\
$\begin{array}{l}\text { Proliferative polyps } \\
\text { Villous adenoma }\end{array}$ & 25 & 3 & 25 & $0.00^{(1)(2)}$ \\
without atypical proliferation & 30 & 8 & 27 & $10.00^{(1)(2)}$ \\
$\begin{array}{l}\text { Villous adenoma with } \\
\text { mild atypical proliferation }\end{array}$ & 60 & 6 & 52 & $13.33^{(1)(2)}$ \\
$\begin{array}{l}\text { Villous adenoma } \\
\text { without atypical proliferatin }\end{array}$ & 40 & 11 & 34 & $15.00^{(1)(2)}$ \\
$\begin{array}{l}\text { Villous adenoma } \\
\text { without atypical proliferatin }\end{array}$ & 25 & 92 & 14 & $44.00^{(1)}$ \\
\begin{tabular}{l} 
Rectal carcinoma \\
\hline
\end{tabular} & 120 & & 28 & 76.67 \\
\hline
\end{tabular}

(1) compared with rectal cancer group, $p<0.01$ : (2) compared with group of villous adenoma with severe atypical proliferation, $p<0.01$.

Table 3: DNA index value of DNA heteroploidy in rectal carcinoma with different differentiation

\begin{tabular}{lccc}
\hline $\begin{array}{l}\text { Pathological diagnosiss } \\
\text { of rectal carcinoma }\end{array}$ & n & $\begin{array}{c}\text { Number of } \\
\text { heteroploidy }\end{array}$ & DI value \\
\hline Well differentiated adenocarcinoma & 33 & 21 & $1.15 \pm 0.12$ \\
Moderately differentiated adenocarcinoma & 29 & 22 & $1.43 \pm 0.18$ \\
$\begin{array}{l}\text { Poorly differentiated adenocarcinoma } \\
\begin{array}{l}\text { Mucinous adenocarcinoma and Signet } \\
\text { ring cell carcinoma }\end{array}\end{array}$ & 27 & 27 & $1.70 \pm 0.23$ \\
\hline
\end{tabular}


the probability of DNA heteroploidy (14) and the higher the degree of atypical hyperplasia, the greater the incidence of cancerous change.

Some researchers showed that the changes in DNA content had appeared in the early-stages of cancer development before atypical hyperplasia or carcinoma in situ could be detected. This happened in various cancer types such as oesophageal carcinoma, breast cancer, oral cancer and laryngeal cancer. DNA imaging analysis might play an important role in prediction of lesion progression and determination of early cancer development (16-19). DNA ploidy analysis has been used to diagnose cervical cancer and its precancerous lesions in some countries for more than 20 years. It has become one of the routine clinical testing methods for the detection of cervical cancer and its precancerous lesions in North America and Europe (20). DNA ploidy analysis of precancerous lesions is a valuable indicator in the prediction and diagnosis of other types of cancers as well.

It was generally agreed that atypical hyperplasia in histology was of great importance in judging cancerous change in cells. However, there were some problems in the application resulting in diagnostic errors. In contrast, DNA heteroploidy spread widely in the mucosa of lesions and appeared earlier, so it could be identified objectively and easily (21). Researches showed that changes of cellular DNA content emerged earlier than changes in cell morphology and measuring the changes of DNA content was therefore superior to observing the changes in the whole cell configuration $(22,23)$. Thus, when findings of cancers on histology are not found, DNA heteroploid can be used as a useful supplement to monitor cancerous change of cells (24). DNA heteroploid status could be used to predict malignant transformation of cells better than other indicators. It could help to identify early invasive cancer which is difficult to be determined by histology and thereby determine those patients with high-risk of cancer who need close follow-up or early intervention.

Colorectal adenoma is now recognized as a precancerous lesion and there have been many relevant research on the DNA ploidy analysis of colorectal adenoma. One study found that DNA heteroploidy played an important role in the process of conversion from adenoma to carcinoma (25), which resulted in the expectations of application of DNA ploidy status in predicting cancerous change and assisting in diagnosis of colorectal cancer.

In this study, we used flow cytometry to analyse the DNA ploidy status in the mucosal cells of the rectum in different pathological specimens. Among these rectal mucosal specimens, the detection rate of DNA heteroploidy in the rectal carcinoma group was the highest $(92 / 120,76.67 \%)$ compared to the other groups. The difference was of statistical significance. DNA heteroploidy was not detected in normal rectal mucosa and hyperplastic polyps. In the groups with rectal villous adenoma, those without atypical hyperplasia had the lowest rate of DNA heteroploidy.
The rate of DNA heteroploidy increased in the order of mild, moderate and severe atypical hyperplasia. Among them, there were significant differences in the positive rate of DNA heteroploidy in the group with severe atypical hyperplasia compared to the other groups. It demonstrated that the positive rate of DNA heteroploidy increased in the process of rectal cancer development. Analysis of rectal carcinoma with several different degrees of differentiation showed that with the decrease of degree of the histological differentiation, the DNA index of heteroploid cells had a tendency to increase. This indicated that the poorer the differentiation of tumour cells, the more severe the degree of their proliferation and abnormal hyperplasia and the higher the degree of malignancy. The results of this study suggested that detection of DNA ploidy status had a very positive clinical significance for clinical diagnosis and prognosis. It may assist in detection, treatment and follow-up of precancerous lesions.

Recent research showed that the assessment of DNA ploidy was a better method than cytopathological examination and detection of serum markers (CEA, CA199, etc) for distinguishing malignant cells $(26,27)$. Another study showed that both aneuploidy and elevated CEA levels could serve for individual risk assessment to predict metachronous metastases in colorectal carcinoma (28). In this study, it was noted that the positive detection rate of DNA heteroploidy in the rectal carcinoma group was $76.67 \%$. That said that the false negative rate is $23.33 \%$ if diagnosing only by DNA heteroploidy, which may also lead to missed diagnosis. On the other hand, although DNA ploidy examination had better sensitivity, because of the higher cost and lack of popularity in clinical application, it had no advantage over conventional cytopathological examination in identification of malignant cells (26). While it is important to follow the ESMO guidelines using a sigmoidoscope or a colonoscope and serum tumour marker analysis (29) for early diagnosis of colorectal carcinoma, it is suggested to improve assessment of the malignant potential and monitoring of malignant progression by the combination of DNA ploidy analysis and other detection methods (30).

In summary, determination of DNA ploidy status in rectal lesions by flow cytometry is a beneficial supplement to clinical and pathological diagnosis of rectal carcinoma. This technology may provide guidance for pathological diagnosis, grading and prognostic judgment of tumours. In practice, DNA ploidy analysis is expected to provide new insights for early detection, diagnosis, efficacy monitoring and prognostic judgment of rectal lesions.

\section{ACKNOWLEDGEMENT}

This research was supported by grants from the Key Scientific and Technological Project of Henan Province in China (No.132102310061).

\section{REFERENCES}

1. Siegel R, Naishadham D, Jemal A. Cancer statistics, 2013. CA Cancer J Clin 2013; 63: 11-30. 
2. Chen HM, Weng YR, Jiang B, Sheng JQ, Zheng P, Yu CG et al. Epidemiological study of colorectal adenoma and cancer in symptomatic patients in China between 1990 and 2009. J Dig Dis 2011; 12: 371-8.

3. Xu AG, Yu ZJ, Jiang B, Wang XY, Zhong XH, Liu JH et al. Colorectal cancer in Guangdong Province of China: a demographic and anatomic survey. World J Gastroenterol 2010; 16: 960-5.

4. Gu J, Chen N. Current status of rectal cancer treatment in China. Colorectal Dis 2013; 15: 1345-50.

5. Lan YT, Yang SH, Lin JK, Lin CC, Wang HS, Chen WS et al. Genetic variations are associated with lymph node metastasis in colorectal cancer patients. J Surg Oncol 2014; 110: 307-12.

6. Schmoll HJ, Van Cutsem E, Stein A, Valentini V, Glimelius B, Haustermans $\mathrm{K}$ et al. 1.ESMO Consensus Guidelines for management of patients with colon and rectal cancer.a personalized approachto clinical decision-making. Annncol 2012; 23: 2479-516.

7. Söderlund S, Tribukait B, Öst Å, Broström O, Karlén P, Löfberg R et al. Colitis-associated DNA aneuploidy and dysplasia in Crohn's disease and risk of colorectal cancer. Inflamm Bowel Dis 2011; 17: 1101-7.

8. Molnar B, Bocsi J, Karman J, Nemeth A, Pronai L, Zagoni T et al. Immediate DNA ploidy analysis of gastrointestinal biopsies taken by endoscopy using a mechanical dissociation device. Anticancer Res 2003; 23: 655-60.

9. Sinicrope FA, Rego RL, Halling KC, Foster N, Sargent DJ, La Plant B et al. Prognostic impact of microsatellite instability and DNA ploidy in human colon carcinoma patients. Gastroenterology 2006; 131: 729-37.

10. Mouradov D, Domingo E, Gibbs P, Jorissen RN, Li S, Soo PY et al. Survival in stage II/III colorectal cancer is independently predicted by chromosomal and microsatellite instability, but not by specific driver mutations. Am J Gastroenterol 2013; 108: 1785-93.

11. Mauland KK, Wik E, Salvesen HB. Clinical value of DNA content assessment in endometrial cancer. Cytometry B Clin Cytom 2014; 86: 154 63.

12. Panousis D, Xepapadakis G, Lagoudianakis E, Karavitis G, Salemis $\mathrm{N}$, Koronakis $\mathrm{N}$ et al. Prognostic value of EZH2, paxillin expression and DNA ploidy of breast adenocarcinoma: correlation to pathologic predictors. J BUON 2013; 18: 879-85.

13. George B, Kopetz S. Predictive and prognostic markers in colorectal cancer. Curr Oncol Rep 2011; 13: 206-15.

14. Furuya T, Uchiyama T, Murakami T. Relationship between chromosomal in stability and intratumoral regional DNA ploidy heterogeneity in primary gastric cancers. Clin Cancer Res 2000; 6: 2815-20.

15. Sugai T, Uesugi N, Habano W, Nakamura S, Suto T, Fujimaki E et al. DNA mapping of gastric cancers using flow cytometric analysis. Cytometry 2000; 42: 270-6.

16. Ottesen GL. Carcinoma in situ of the female breast. A clinicopathological, immunohistological, and DNA ploidy study. APMIS Suppl 2003; 108: $1-67$.

17. Zhang X, Huang Q, Goyal RK, Odze RD. DNA ploidy abnormalities in basal and superficial regions of the crypts in Barrett's esophagus and associated neoplastic lesions. Am J Surg Pathol 2008; 32: 1327-35.
18. Mattila R, Alanen K, Syrjänen S. Desmocollin expression in oral atrophic lichen planus correlates with clinical behavior and DNA content. J Cutan Pathol 2008; 35: 832-8.

19. Yuan Y, Chi F, Wang S, Wang Z. Significance of ceramide and DNA ploidy in laryngeal carcinogenesis. ORL J Otorhinolaryngol Relat Spec 2007; 69: 283-8.

20. Remmerbach TW, Weidenbach H, Pomjanski N, Knops K, Mathes $\mathrm{S}$, Hemprich A et al. Cytologic an DNA-cytometric early diagnosis of oral cancer. Anal Cell Patho 2001; 22: 211-21.

21. Yasa MH, Bektas A, Yukselen V. DNA analysis and DNA ploidy in gastric cancer and gastric precancerous lesions. Int J Clin Pract 2005; 59: 1029-33.

22. Hirshberg A, Yarom N, Amariglio N, Yahalom R, Adam I, Stanchescu $\mathrm{R}$ et al. Detection of non-diploid cells in premalignant and malignant oral lesions using combined morphological and FISH analysis - a new method for early detection of suspicious oral lesions. Cancer Lett 2007; 253: 28290.

23. Abou-Elhamd KE, Habib TN. The flow cytometric analysis of premalignant and malignant lesions in head and neck squamous cell carcinoma. Oral Oncol 2007; 43: 366-72.

24. Sperandio M, Brown AL, Lock C, Morgan PR, Coupland VH, Madden $\mathrm{PB}$ et al. Predictive value of dysplasia grading and DNA ploidy in malignant transformation of oral potentially malignant disorders. Cancer Prev Res (Phila) 2013; 6: 822-31.

25. Alcántara Torres M, Rodríguez Merlo R, Repiso Ortega A, de Lucas Veguillas A, Valle Muñoz J, Sánchez Simón R et al. DNA aneuploidy in colorectal adenomas. Role in the adenoma-carcinoma sequence. Rev Esp Enferm Dig 2005; 97: 7-15.

26. Sayed DM, el-Attar MM, Hussein AA. Evaluation of flow cytometric immunophenotyping and DNA analysis for detection of malignant cells in serosal cavity fluids. Diagn Cytopathol 2009; 37: 498-504.

27. Palaoro LA, Blanco AM, Gamboni M, Rocher AE, Rotenberg RG. Usefulness of ploidy, AgNOR and immunocytochemistry for differentiating benign and malignant cells in serous effusions. Cytopathology 2007; 18: 33-9.

28. Laubert T, Bente V, Freitag-Wolf S, Voulgaris H, Oberländer M, Schillo $\mathrm{K}$ et al. Aneuploidy and elevated CEA indicate an increased risk for metachronous metastasis in colorectal cancer. Int $\mathrm{J}$ Colorectal Dis 2013; 28: 767-75.

29. Labianca R, Nordlinger B, Beretta GD, Brouquet A, Cervantes A. ESMO Guidelines Working Group: Primary colon cancer: ESMO Clinical Practice Guidelines for diagnosis, adjuvant treatment and follow-up. Annals of Oncology 2010; 21 (Supplement 5): v70-v77.

30. Siebers TJ, Bergshoeff VE, Otte-Höller I, Kremer B, Speel EJ, van der Laak JA et al. Chromosome instability predicts the progression of premalignant oral lesions. Oral Oncol 2013; 49: 1121-8. 